\title{
PENDIDIKAN POLITIK BAGI SISWA KELAS XII BERBASIS KEARIFAN LOKAL DI KECAMATAN PAHANDUT KOTA PALANGKA RAYA
}

\author{
Political Education For Xii Grade Students Based On Local Wisdom In Pahandut Distric \\ Kota Palangka Raya
}

\section{Alfrid Sentosa ${ }^{\prime *}$ \\ Wiwik Suprapti ${ }^{2}$}

\begin{abstract}
Abstrak
Tujuan penelitian ini adalah: I) untuk menggambarkan bentuk-bentuk pendidikan politik berbasis kearifan lokal di Kecamatan Pahandut Kota Palangka Raya. 2) Untuk mengetahui Faktor-faktorapa yang menjadi penghambat dalam memberikan pendidikan politik di Kecamatan Pahandut Kota Palangka Raya.

Penelitian ini bersifat deskriptif dengan penjelasan kualitatif. Deskriptif dapat diartikan sebagai prosedur pemecahan masalah yang diselidiki dengan menggambarkan/melukiskan keadaan subyek/obyek penelitian (seseorang, lembaga, masyarakat, dan lain-lain) pada saat sekarang berdasarkan fakta-fakta yang tampak atau sebagaimana adanya.

Hasil Penelitian a) Pedidikan politik non formal adalah pendidikan yang didapatkan oleh siswa XII diluar jam sekolah adau dirumah yaitu dalam bentuk nilai luhur yang di turunkan secara turun temurun baik melalui budaya, adat istiadat serta kearifan lokal setempat. b) Pendidikan politik formal biasa didapatkan oleh siswa yaitu di sekolah yang diberikan oleh guru atau pun pihak yang terkait didalannya seperti KPU, Bawaslu dan Lainnya. Melalui pelajaran PKn guru memberikan pengetahuan tentang pendidikan politik bahwa mereka memiliki hak suara berhak untuk memilih dan di pilih apabila sudah berumur 17 tahun. Dalam memberikan pendidikan politik ada beberapa hal yang menjadi pengambat yaitu: Kurangnya sosialisasi yang diberikan kepada siswa XII, kurangnya pengetahuan siswa tentang seni budaya, adat istiadat, kearifan lokal setempat, adanyan kendala dari pihak penyelenggara dalam memberikan sosialiasi kepada pemilih kelas XII yang telah berumur 17 tahun karena wabah virus corona Covid 19, pendidikan disekolah kurang maksimal juga dalam memberikan pendidikan politik karena siswa sekolah dari rumah.
\end{abstract}

Kata Kunci:

Pendidikan Politik

Berbasis Kearifan Lokal

Keywords:

Political education

Based on local wisdom

\begin{abstract}
The objectives of this study are: I) to describe forms of political education based on local wisdom in Pahandut District, Palangka Raya City. 2) To find out what factors are as the obstacles in providing political education in the Pahandut District of Palangka Raya City. This research is descriptive with a qualitative explanation. Descriptive can be defined as a procedure for solving problems that are investigated by describing / describing the condition of the subject / object of research (a person, institution, society, etc.) at the present time based on visible facts or as they are.

The results of this research are: a) Non-formal political education is education that is obtained by XII grade students outside of school time or at home, which is in the form of noble values passed down from generation to generation through culture, traditions, and local wisdom. b) Formal political education is usually obtained by XII grade students in schools provided by teachers or parties related to them such as the General Election Commissions (KPU), General Election Supervisory Agency (Bawaslu), and others. Through the Civics subject, the teacher provides knowledge about political education that they have voting rights, where they have the right to vote and be elected when they turn 17 years old. In providing political education there are several obstacles, namely: Lack of outreach services provided to XII students; lack of student knowledge about cultural arts, traditions, and local wisdom; constraints on the part of the organizer in providing outreach services to class XII voters who are 17 years old; due to the COVID 19 pandemic, school education has not been optimal in providing political education because students are studying from home.
\end{abstract}




\section{PENDAHULUAN}

Pendidikan merupakan usaha yang disengaja dan terencana untuk membantu perkembangan dan potensi kemampuan individu agar bermanfaat bagi kepentingan hidupnya baik sebagai individu maupun dalam anggota masyarakat. Belajar memberi, belajar menerima, belajar bersabar, belajar menghargai, dan belajar menghormati. Pendidikan politik harus diberikan sejak dini kepada siswa-siswi SMA atau masyarakat secara luas agar para calon pemilih pemula nantinya sudah memiliki bekal pada saat memberikan hak suaranya ketika pemilu berlangsung.

Pendidikan Pemilih Menjadi Jantung Penyelenggaraan Pemilu Untuk Menciptakan Pemilih Yang Rasional, Yakni Pemilih Yang Menentukan Pilihannya Bukan Karena Adanya Tekanan, Maupun Politik Uang, Melainkan Memilih Karena Visi, Misi, Kredibilitas Partai Politik Maupun Calon Yang Akan Dipilihnya. Disinilah Komisi Pemilihan Umum Memainkan Perannya Bagaimana Menjadikan Pemilih Memahami Bahwa Pemilu Merupakan Sebuah Proses Demokrasi Pergantian Pimpinan Yang Sudah Terpola.

Kearifan lokal merupakan bagian dari budaya suatu masyarakat yang tidak dapat dipisahkan dari bahasa masyarakat itu sendiri. Kearifan lokal (local wisdom) biasanya diwariskan secara turun temurun dari satu generasi ke generasi melalui cerita dari mulut ke mulut. Kearifan lokal ada di dalam cerita rakyat, peribahasa, lagu, dan permainan rakyat. Kearifan lokal sebagai suatu pengetahuan yang ditemukan oleh masyarakat lokal tertentu melalui kumpulan pengalaman dalam mencoba dan diintegrasikan dengan pemahaman terhadap budaya dan keadaan alam suatu tempat (Padmanugraha, 2010:12).

Masing-masing daerah mempunyai keunggulan potensi daerah yang perlu dikembangkan yang lebih baik lagi. Keunggulan yang dimiliki oleh masing-masing daerah sangat bervariasi. Dengan keberagaman potensi daerah ini perlu mendapat perhatian khusus bagi pemerintah daerah sehingga anak-anak tidak asing denga daerahnya sendiri dan faham betul tentang potensi dan nilai-nilai serta budaya daerahnya sendiri sesuai dengan tuntunan ekonomi global. Kearifan lokal biasanya berkembang di masyarakat melalui tradisi lisan misalnya seperti manuggal yang terdapat di Kalimantan Tengah. Ciri dari kearifan lokal sendiri adalah mampu bertahan terhadap budaya-budaya dari luar atau budaya baru dan memiliki kemampuan untuk mengakomodasi unsur-unsur budaya asing.

Di tengah pusaran pengaruh hegemoni global tersebut, fenomena yang terjadi juga telah membuat lembaga pendidikan serasa kehilangan ruang gerak. Selain itu juga membuat semakin menipisnya pemahaman peserta didik tentang sejarah lokal serta tradisi budaya yang ada dalam masyarakat. Oleh karena itu maka alangkah lebih baiknya jika diupayakan bagaimana caranya agar aneka ragam budaya yang telah kita miliki tersebut bisa kita jaga dan kita lestarikan bersama. Dengan pendidikan yang berbasis pada local wisdom (kearifan lokal) maka kita bisa optimis akan terciptanya pendidikan yang mampu memberi makna bagi kehidupan manusia Indonesia kususunya dalam penerapan pendiidkan politik berbasis kearifan lokal.

Dari fenomena diatas maka permasalahan yang diajukan dalam penelitian ini ada 2 yaitu: I) Bagaimana bentukbentuk pendidikan politik berbasis kearifan lokal di Kecamatan Pahandut Kota Palangka Raya? Faktor-faktor apa yang menjadi penghambat dalam memberikan pendidikan politik di Kecamatan Pahandut Kota Palangka Raya?

Tujuan penelitian ini adalah: I) untuk menggambarkan bentuk-bentuk pendidikan politik berbasis kearifan lokal di Kecamatan Pahandut Kota Palangka Raya? 2) untuk mengetahui Faktor-faktor apa yang menjadi penghambat dalam memberikan pendidikan politik di Kecamatan Pahandut Kota Palangka Raya?

\section{Pengertian Pendidikan Politik}

Menurut Muhibbin syah (2010:10) Pendidikan berasal dari kata "didik", lalu kata ini mendapatkan awalan me 
sehinga menjadi "mendidik", artinya memelihara dan memberi latihan. Dalam memelihara dan memberi latihan diperlukan adanya ajaran, tuntunan, dan pimpinan mengenaik ahlak dan kecerdasan pikiran.

Pendidikan adalah proses yang dilakukan secara sengaja untuk menggali dan mengembangkan potensi yang ada pada peserta didik supaya mereka memiliki kemampuan dalam menaggapi lingkungan secara positif dan senantiasa melakukan perubahan baik secara pengetahuan, sikap, maupun perilaku yang memiliki makna bagi dirinya sendiri, masyarakat dan lingkungannya. Pendidikan politik merupakan proses interaksi antara pendidik (sekolah, partai politik, maupun pemerintah) dalam rangka memberikan pemahaman, penghayatan, dan pengamalan nilai maupun norma politik yang dianggap baik dan ideal. (Rahmat, Amarru Mufftie H, lqbal S20 I8 Hal I I9I-1202).

Pendidikan politik merupakan suatu proses dialogis antara pemberi dan penerima pesan, melalui pesan ini para anggota masyarakat mengenal dan mempelajari nilai-nilai, norma-norma, dan simbol-simbol politik yang ideal dari berbagai pihak dalam sistem politik, seperti pemerintah, sekolah, partai politik, Pendidikan politik adalah usaha sadar untuk mengubah proses sosialisasi politik masyarakat, sehingga mereka memahami dan menghayati betul nilai-nilai yang terkandung dalam suatu sistem politik yang ideal yang hendak dibangun. (Sunarso, 2007 jurnal civics vol 4 (2).

Pendidikan politik adalah upaya edukatif yang internasional, disengaja dan sitematis untuk membentuk individu sadar politik, dan mampu menjadi pelaku politik yang bertanggung jawab secara etis/moril dalam mencapai tujuan-tujuan politik (Aris Riswandi Sanusi, 2016. JPIS Jurnal Pendidikan IImu Sosial Vol. 25 (I)).

Pendidikan politik merupakan proses dialog antara pendidik, seperti sekolah, pemerintah, partai politik, dan peserta didik dalam rangka pemahaman, penghayatan dan pengamatan nilai, norma dan simbol politik yang dianggap idel dan baik. Melalui kegiatan kursus latihan kepemimpinan, diskusi, dan keikutsertaan dalam berbagai forum pertemuan, partai politik dalam sistem politik demokrasi dapat melaksanakan fungsi pendidikan politik. (Dwira Kharisma, 2015 Jurnal Politico Vol 4. (2)).

Pendidikan politik masyarakat adalah merupakan rangkaian usaha untuk mewujudkan masyarakat adil dan makmur berdasarkan pancasila. Pendidikan politik juga merupakan bagian proses pembaharuan kehidupan politik bangsa Indonesia yang sedang dilakukan dewasa ini dalam rangka menciptakan suatu sistem politik yang benar-benar demokratis, dinamis, dan efisien (Payerli Pasaribu, 2017. JPPUMA: Jurnal Ilmu Pemerintahan dan Sosial Politik UMA Vol 5 No I).

\section{Pendidikan Politik Berbasis Kearifan Lokal}

Istilah lokal secara spesifik menunjuk pada ruang interaksi terbatas dengan sistem nilai yang terbatas pula. Sebagai ruang interaksi yang sudah didesain sedemikian rupa yang di dalamnya melibatkan suatu pola-pola hubungan antara manusia dengan manusia atau manusia dengan lingkungan fisiknya. Pola interaksi yang sudah terdesain tersebut disebut setting. Setting adalah sebuah ruang interaksi tempat seseorang dapat menyusun hubungan-hubungan face to face dalam lingkungannya. Sebuah setting kehidupan yang sudah terbentuk secara langsung akan memproduksi nilai-nilai. Nilai-nilai tersebut yang akan menjadi landasan hubungan mereka atau menjadi acuan tingkah-laku mereka.

Kearifan lokal atau sering disebut local wisdom dapat dipahami usaha manusia dapat dipahami sebagai usaha manusia dengan menggunakan akal budinya (kognisi) untuk bertindak dan bersikap terhadap sesuatu, objek, atau peristiwa yang terjadi dalam ruang tertentu. Pengertian tersebut disusun secara etimologi, di mana wisdom dipahami sebagai kemampuan seseorang dalam menggunakan akal pikirnya dalam bertindak atau bersikap sebagai hasil penilaian terhadap suatu objek atau peristiwa yang terjadi. Sebagai sebuah istilah wisdom sering diartikan sebagai kearifan atau kebijaksanaan (Ridwan, 2007: 2-3). 
Kearifan lokal merupakan bentuk dialektika antara manusia dengan pengetahuan kehidupan. Pengetahuan yang diambil dari kehidupan di mana manusia itu berada kemudian direfleksikan untuk membantu manusia memaknai kehidupan. Sebagai pedoman masyarakat, selanjutnya kearifan lokal memberi panduan yang jelas ranah-ranah yang dapat dijangkau oleh tingkah laku manusia.

Dalam proses terbentuknya, kearifan lokal tidak dikonsepsikan secara individu namun membutuhkan peran komunal yakni masyarakat. Selanjutnya kearifan lokal menjadi bagian dari budaya untuk kemudian menjadi identitas bahkan karakter suatu masyarakat. Karenanya, antara kearifan lokal dan budaya merupakan hubungan antara anak dengan induknya. Kearifan lokal tidak lain adalah bagian dari budaya.

Koentjaraningrat (1984: 8-25) mengatakan bahwa nilai budaya adalah lapisan abstrak dan luas ruang lingkupnya. Tingkat ini adalah ide-ide yang mengkonsepsikan hal-hal yang paling bernilai dalam kehidupan masyarakat. Suatu sistem nilai budaya terdiri atas konsepsi-konsepsi yang hidup dalam pikiran sebagian besar warga masyarakat mengenai hal-hal yang harus mereka anggap bernilai dalam hidup. Oleh karena itu, suatu sistem nilai kebudayaan biasanya berfungsi sebagai pedoman tertinggi bagi kelakuan manusia. Sistem kelakuan manusia lain yang tingkatannya lebih konkret, seperti aturan-aturan khusus, hukum, dan norma-norma, semuanya juga berpedoman pada nilai budaya itu. nilai budaya yang dapat mendorong pembangunan, di antaranya sifat tahan penderitaan, berusaha keras, toleran terhadap pendirian atau kepercayaan orang lain, dan gotong-royong.

Kearifan lokal dilihat dari kamus Inggris Indonesia, terdiri dari dua kata yaitu kearifan (wisdom) dan lokal (local). Local berarti setempat dan wisdom sama dengan kebijaksanaan. Dengan kata lain maka local wisdom dapat dipahami sebagai gagasan-gagasan, nilai-nilai-nilai, pandangan-pandangan setempat (local) yang bersifat bijaksana, penuh kearifan, bernilai baik, yang tertanam dan diikuti oleh anggota masyarakatnya.

Pendidikan berbasis kearifan lokal adalah pendidikan yang mengajarkan peserta didik untuk selalu lekat dengan situasi konkret yang mereka hadapi. Paulo Freire (Wagiran, 2010) menyebutkan, dengan dihadapkan pada problem dan situasi konkret yang dihadapi, peserta didik akan semakin tertantang untuk menanggapinya secara kritis. Hal ini selaras dengan pendapat Suwito yang mengemukakan pilar pendidikan kearifan lokal meliputi:

I) membangun manusia berpendidikan harus berlandaskan pada pengakuan eksistensi manusia sejak dalam kandungan,

2) pendidikan harus berbasis kebenaran dan keluhuran budi, menjauhkan dari cara berpikir tidak benar dan grusa-grusu atau waton sulaya,

3) pendidikan harus mengembangkan ranah moral, spiritual (ranah afektif) bukan sekedar kognitif dan ranah psikomotorik, dan sinergitas budaya, pendidikan dan pariwisata perlu dikembangkan secara sinergis dalam pendidikan yang berkarakter (2008).

Berdasarkan pengertian di atas, dapat dipertegas bahwa kearifan lokal merupakan sebuah budaya kontekstual. Kearifan selalu bersumber dari hidup manusia. Ketika hidup itu berubah, kearifan lokal pun akan berubah pula.

\section{Kerangka Pikir}

Kerangka Pemikiran dalam penelitian ini dapat digunakan sebagai berikut :

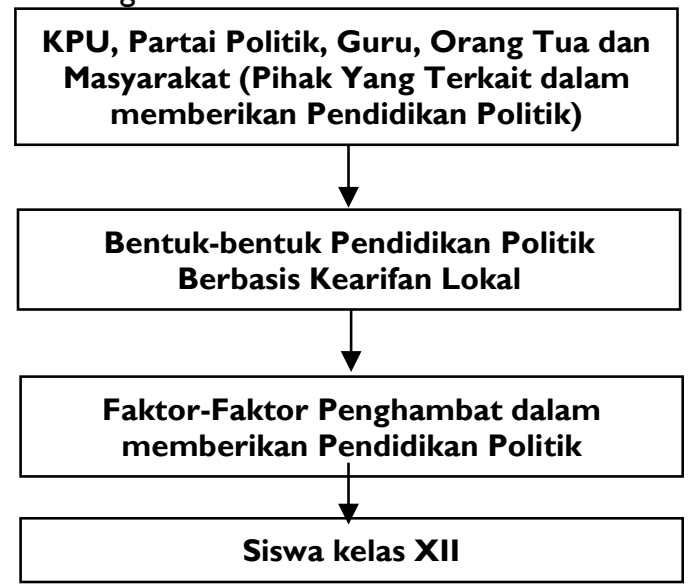




\section{METODOLOGI}

Penelitian ini bersifat deskriptif dengan penjelasan kualitatif. Marshal dalam Sarwono Penelitian Kualitatif didefinisikan sebagai suatu proses yang mencoba untuk mendapatkan pemahaman yang lebih baik mengenai kompleksitas yang ada dalaminteraksi manusia (Sarwono, Jonathan 2006:193).

Teknik pengumpulan data dalam penelitian ini yaitu dengan menggunakan: observasi, wawancara dan dokumentasi.

Peneliti menggunakan model analisis interaktif yang dikembangkan oleh Miles dan Huberman (1992: 5-20) dimana data yang dikumpulkan akan dianalisis melalui tiga tahap yaitu mereduksi data, menyajikan data, dan menarik kesimpulan.

\section{HASIL DAN PEMBAHASAN}

\section{Kearifan Lokal Kalimantan Tengah}

Kearifan local harus tetapa di pertahankan karena didalamnya terdapat pandangan, aturan, nilai, serta norma. Dengan semakin berkembangnya jaman akan mengancam keberlangsungan kearifan local suatu daerah. Suatu kearifan lokal yang berlaku di suku Dayak Kalimantan Tengah adalah wujud dari suatu proses yang panjang dan dilakukan secara berulang-ulang secara terus menerus dalam jangka waktu yang panjang dan memiliki nilai leluhur dengan adanya kebudayaan sebagai bukti kongkrit. Nilai tersebut terdiri atas nilai sejarah, nilai social, nilai ekonomi dan nilai lingkungan. Nilai sejarah atau histori yaitu keteladanan, keberanian, tanggung jawab, dan rela berkorban. Nilai sosialnya yaitu solidaritas, kerjasama, gotong royong, kebersamaan dan sopan santun. Nilai ekonomi yaitu kemandirian, kesederhanaan dan produktivitas. Pendidikan berbasis kearifan lokal merupakan pendidikan yang berdasarkan pada nilai-nilai kultur atau budaya dimana pendidikan ini, mengajarkan pada hal-hal nyata yang terjadi keseharian pada peserta didik dan mengajarkan nilai yang berlaku di sebuah masyarakat.
Kearifan lokal memiliki makna dan gagasan yang bersifat bijaksana, penuh kearifan, bernilai baik yang tertanam dan melekat pada sebuah masyarakat. Kearifan lokal juga memiliki fungsi seperti yang dijelakan oleh Sartini (2006) bahwa fungsi kearifan lokal adalah: I) konservasi dan pelestarian sumberdaya alam, 2) pengembangan sumber daya manusia, 3) pengembangan kebudayaan dan ilmu pengetahuan, 4) petuah, kepercayaan, sastra dan pantangan, 5) bermakna sosial missal upacara integrase komunal/kerabat, 6) bermakna etika dan moral, dan 7) bermakna politik

Bentuk-bentu kearifan lokal yang tergambar yaitu adanya kerukunan yang terjalin antar umat beragama dalam wujud praktik sosial yang dilandasi suatu kearifan dari budaya. Keberlanjutan dan keseimbangan kearifan lokal dalam suatu masyarakat dapat bersifat budaya (nilai, norma, etika dan kepecayaan adat istiadat, hokum adat, serta adanya aturan khusus). Nilai luhur berkaitan dengan kearifan lokal yaitu cinta kepada Sang Pencipta alam semesta beserta isinya, tanggung jawab, disiplin, mandiri, jujur, hormat, dan santun, kasih saying dan peduli, percaya diri, kreatuf, kerja keras, dan pantang menyerah (Isen Mulang) keadilan dan kepemimpinan, baik dan rendah hari, toleransi, cinta damai dan persatuan.

Kearifan lokal sebagai modal dasar pembentukan karakter dan memberikan pendidikan sejak dini agar memiliki karakter yang baik dan luhur. Karakter baik dan luhur adalah wajah bangsa yang senantiasa bertindak dengan penuh kesadaran, pengendalian diri dan menjadi identitas diri. Sartini (Rahardjo, dkk. 20I2) menerangkan bahwa identitas budaya juga sering disebur dengan lokal genius yang sering dipahami sebagai identitas atau kepribadian budaya suatu masyarakat.

\section{Huma Betang}

Betang merupakan tempat tinggal permanen untuk beberapa generasi, dibangun di desa oleh beberapa kepala keluarga yang masih memiliki ikatan pertalian darah/keturunan atau rumah yang menampung banyak 
keluarga di dalamnya. Walaupun rumah Betang menampung banyak keluarga yang ditampung dan hidup dalam satu atap, tetapi mereka memiliki pemimpin atau Kepala Adat/Panglima perang yang dapat melindungi mereka dari serangan musuh, yaitu seperti Betang Buntoi dipimpin oleh Singa Djala, Betang Tumbang Korik di pimpin oleh Singa Kiting, Betang Tumbang Anoi di pimpin Oleh Damang Batu.

Secara filosofis sebutan Huma Betang juga dapat diartikan sebagai suatu perwujudan budaya hidup bersama dalam satu atap, kegotong royongan, saling pengertian dalam naungan hukum adat yang jelas. Beberapa kontruksi nilai budaya Huma Betang yaitu : a) Hampahari, sebagai persaudaraan dan kebersamaan dalam kehidupan di betang, b) Handep, merupakan tolong-menolong, pandohop, (bantuan), saling mandohop (membantu), c) Belom Bahadat, hidup beradab dan memiliki etika yaitu menghargai adat yang berlaku dalam wilayah komunitas adat, d) Hapakat Kula, saling bermufakat menyangkut kepentingan bersama harus diputuskan secara bersama melalui mufakat.

\section{Isen Mulang}

Isen mulang adalah sebuah ungkapan dari Tjilik Riwut yang menjadi slogan kekuatan masyarakat Kalimantan Tengah ungkapan itu berarti "Pesanku Jangan Menyerah" yang saat ini menjadi slogan dan kekuatan masyarakat Kalimantan Tengah.

\section{Salam Adat Dayak}

Tabe saamat lingu nalatai, Salam judud karendem malempang, Adil katalino basurat mi kasaruga, Basengat kajubata. Dijawab Harus.

Artinya salam sejahtera dan damai selalu, selamat bertemu semoga dalam keadaan bahagia.

\section{Seni}

Seni suku Dayak asli Kalimantan Tengah memiliki warisan di bidang seni yang diwariskan secara turun temurun, yaitu seni music, suara dan tari. Pada music masyarakat Dayak Kalimantan Tengah gemar melantunkan ungkapan hati dan perasaan, kisah kehidupan dan kepahlawanan sukunya dalam kalimat berirama yang disebut Karungut yang dilantunkan sejenis pantun yang dilantunkan pada acara penyambutan tamu. Sedangkan untuk seni tari masyarakat Kalimantan Tengah memiliki banyak macam tari salah satunya tari Manasai ialah tarian pergaulan yang sampai saat ini tarian ini diwariskan oleh orang tua untuk bias melakukannya sebagai wajud warisan budaya. Dan tarian untuk menyambut tamu adalah tarian Kinyah/Tari Perang/Tari Mandau. Tari inu adalah untuk menyambut tamu yang hadir pada acara resmi dan pertunjukan tari.

\section{Bentuk-Bentuk Pendidikan Politik Berbasis Kearifan Lokal}

Pendidikan politik sangat penting di berikan sejak dini kepada pemilih pemula, karena pada prinsipnya pendikan politik kepada generasi muda adalah rangkaian usaha untuk meningkatkan dan memantapkan kesadaran politik dan kenegaraan guna menunjang kelestarian Pancasila dan UUD 1945 sebagai budaya politik bangsa. Menurut Kuntowijoyo (1994; 58) mengemukakan tentang bentuk pendidikan politik, yaitu: I) pendidikan politik formal yakni pendidikan politik yang diselenggarakan melalui indoktrinasi, 2) pendidikan politik yang dilakukan secara nonformal, seperti melalui pertukaran pendidikan melalui mimbar bebas.

Pendidikan politik adalah suatu langkah dalam mewujudkan karakter bangsa, Istilah lokal; adalah menunjukan pada ruang interaksi terbatas dengan sistem nilai yang terbatas pula. Sebagai ruang interaksi yang sudah didisain sedemikian rupa yang didalamnya melibatkan suatu pola-pola hubungan antara manusia dengan lingkungan secara fisiknya. Hubungan itu dijalin face to face antara manusia satu dengan yang lainnya dalam suatu lingkungan. Didalam hubungan tersebut ada nilai-nilai yang terbentuk sacara turun-temurun yang akan menjadi pondasi acuan tingkah laku mereka.

Kearifan lokal masing-masing daerah pastinya berbedabeda dan yang masti memiliki nilai yang luhur serta dihormati dalam menjalakan kehidupan sosial. Kearifan lokal sering disebut dengan local wisdom dapat 
dimengerti bahwa manusia dengan menggunakan akal budinya (kognisi) untuk bertindak dan bersikap terhadap sesuatu, objek, atau peristiwa yang terjadi dalam ruang tertentu.

Keraifan lokal mengajarkan manusia untuk dapat memahami tentang pengetahuan dalam hidup, baik diri sendiri ataupun secara keseluruhan dalam bermasyarakat. Selanjutnya dalam terbentuknya kearifan lokal adalah bagian dari budaya yang kemudian menjadi identitas bahkan karakter suatu masyarakat. Karena kearifan lokal adalah bagian dari budaya.

Pahandut adalah sebuah Kecamatan yang ada di Kota Palangka Raya yang kental dengan budaya dan kearifan lokal suku Dayak Kalimantan Tengah dari hasil wawancara dengan KPU Kota Palangka Raya yaitu dengan Bapak H.M Syairi Abdullah mengatakan bahwa KPU juga memberikan pendidikan politik dengan cara mengikutsertakan unsur budaya Dayak contohnya mengadakan lomba tari untuk pelajar, pidato, serta memasukan atribut suku Dayak dalam spanduk sosialisasi.

Tahun ini KPU Provinsi mengangkat maskot peilihan kepala daerah dengan Simbol Balanga lengkap dengan artinya dengan tujuan agar masyarakat Dayak khusunya pemilih pemula juga tertarik dan dapat berpartisipasi dalam pemilihan tahun 2020 yaitu pemilihan Gubernur dan Wakil Gubernur Kalimantan Tengah.

Dalam wawancara bersama dengan Bapak H.M Syairi Abdullah juga mengatakan dalam memberikan pendidikan politik dengan berbasis kepada kearifan lokal yaitu dengan cara memasukan dalam spanduk sosialisasi dengan menggunakan Bahasa daerah agar mudah dipahami dan dimengerti masyarakat lokal.

Tahun ini KPU Provinsi memiliki maskot yaitu "BALANGA PERSATUAN" yang di singkat dengan Baper yaitu:

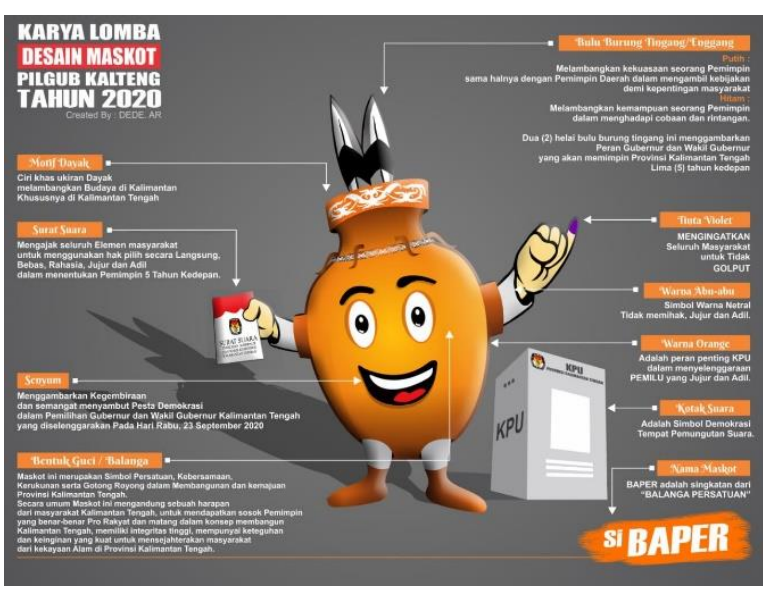

Gambar I Maskot KPU Provinsi Kalimantan Tengah 2020

Maskot diatas diambil dari Balanga yang mana Balanga adalah sebuah guci keramik suku Dayak yang biasa difungsikan juga sebagai barang adat pada acara peminangan dan tempat menyuguhkan makanan bagi para leluhur, guci memiliki nilai luhur yang sacral bagi orang Dayak. Balanga juga sebagai lambing logo untuk Provinsi Kalimantan Tengah dengan mengangkat Balanga sebagai maskot KPU Provinsi Kalimantan Tengah adalah bertujuan untuk memperkenalkan kearifan lokal suku Dayak seperti pejelasan pada gambar diatas Balanga dikatakan sebagai simbol persatuan, kebersamaan, kerukunan serta gotong royong dalam membangun dan memajukan Kalimantan Tengah, Bulu Burung Tingang/Enggang yang warna putih melambangka kekuasaan pemimpin dan yang hitam melangbangkan kemampuan seorang pemimpin dalam menghadapi cobaan dan rintangan.

Dari hasil wawancara dengan anggota partai politik Bapak Subandi mewakili Golkar menerangkan selama ini Golkar juga turut memberikan pendidikan secara tidak langsung kepada Siswa dan siswi yang umurnya sudah mendekaki 17 tahun, dengan melakukan pengkaderan kepada generasi muda.

Serta juga hasil wawancara dengan Bapak Sigit Selaku mewakili Partai PDI Perjuangan mengtakan bahwa dalam memberikan pendidikan politik mereka terjunlangsung kelapangan sesuai dengan program yang telah dibuat 
oleh partai dengan cara memfasilitasi tryout kelas XII dengan cara itu akan diperkenalkan kepada mereka siapa saja perwakilan Legislatif dari partai PDI Perjuangan. Memang secara sepesifik dari anggota partai belum begitu banyak membuat program untuk pendidikan politik apalagi berbasis kearifan lokal Hasil dari wawancara bersama dengan 3 orang guru yang mengajar dan sering bertemu dengan siswa calon pemilih pemula telah memberikan pendidikan politik memperkenalkan dan menjelaskan bahwa setiap warga negara memiliki hak untuk memilih dan dipilih apabila usia sudah 17 tahun. Guru-guru juga menerangkan dan mengajarkan nilai-nilai budaya yaitu dengan mengajar kepada siswa bernyanyi lagu daerah, menjelaskan tentang Isen Mulang, menjelskan tentang arti Huma Betang. Secara tidak langsung guru-guru sudah menanamkan nilai kearifan lokal kepada siswa yang dididik tersebut, mengajarkan dan menumbuhkan nilai luhur yang sudah turun temurun ada di masyarakat.

Pendidikan politik juga diberikan melalui mata pelajaran PPKn, pemberian pendidikan politik melalui mata pelajaran PPKn adalah salah satu cara untuk meningkatkan kesadaran politik siswa, khususnya siswa kelas XII di Kecamatan Pahandut agar dapat lebih memahami tentang politik.

Siswa XII adalah calon pemilih pemula yang $80 \%$ dari jumlah keseluruhan di kelas XII Daerah Pahandut adalah berusia 17 tahun, mereka sudah berhak memilih pada tahun 2020 yaitu pemilihan Gubernur dan Wakil Gubernur. Sebagian besar ketika di wawancara $90 \%$ sudah memiliki pengalaman dalam memberikan hak suara, karena di sekolah telah di ajarkan bagaimana cara menyalurkan hak suara yaitu dengan pemilihan Osis atau ketua kelas.

Disain pendidikan politik berbasis kearifan lokal memang belum ada secara pasti di berikan di sekolah, tetapi dengan siswa ikut lomba tari daerah, menyanyikan lagu Dayak ketika masuk dan keluar ruangan adanya pelajaran Mulok sebagain besar nilai-nilai luhur kearifan lokal itu diajarkan. Secara tidak langsung bahwa itu yang akhirnya membentuk karakter murid berdasarkan nilai luhur yang diajarkan oleh guru disekolah.

\section{Faktor-Faktor Penghambat Dalam Memberikan Pendidikan Politik}

Adapun faktor-faktor penghambat dalam memberikan pendidikan politik adalah:

I. Kurangnya sosialisasi yang diberikan kepada siswa kelas XII baik dari pihak penyelenggara ataupun partai politik, pendidikan politik sangat penting diberikan sejak dini kepada para siswa sehingga mereka mendapatkan pengetahuan tentang politik lebaih awal.

Dalam memberikan pendidikan politik juga dapat melibatkan banyak unsur didalamnya, misalnya sekolah dapat mengundang seorang anggota DPR dalam memberikan materi seminar yang diadakan oleh sekolah, kepolisian, KPU, Bawaslu sehingga ini dapat memperkaya pengetahuan dari siswa.

2. Bentuk kearifan lokal di Kalimantan Tengah harus tetap lelastarikan karena siswa sebagian besar kurang mencintai budaya lokal, sehingga apabila pengenalan akan budaya dan kearifal lokal sudah dilakukan sejak dini maka siswapun akan mencitai dan ikut melestarikan budaya lokal untuk dipertahankan.

3. Pada masa pandemic CovidI9 KPU mendapatkan beberapa faktor yang memnghabat dalam memberikan sosialisasi karen tidak dapat mengumpulkan orang banyak, sosialisasi hanya dapat di lakukan melalui webside, instgram, facebook, whatshapp dan media-media lain yang berbentuk virtual khusus untuk pemilih pemula.

4. Siswa disekolah tidak banyak mendapatkan info tentang perpolitikan karena sedang libur, guru PKn terbatas dalam memberikan pendidikan baik tentang kewarganegaraan dan politik 


\section{KESIMPULAN}

Pedidikan politik non formal adalah pendidikan yang didapatkan oleh siswa XII diluar jam sekolah adau dirumah yaitu dalam bentuk nilai luhur yang di turunkan secara turun temurun baik melalui budaya, adat istiadat serta kearifan lokal setempat. Pendidikan politik formal biasa didapatkan oleh siswa yaitu di sekolah yang diberikan oleh guru atau pun pihak yang terkait didalannya seperti KPU, Bawaslu dan Lainnya. Melalui pelajaran PKn guru memberikan pengetahuan tentang pendidikan politik bahwa mereka memiliki hak suara berhak untuk memilih dan di pilih apabila sudah berumur 17 tahun. Dalam memberikan pendidikan politik ada beberapa hal yang menjadi pengambat yaitu: Kurangnya sosialisasi yang diberikan kepada siswa XII, kurangnya pengetahuan siswa tentang seni budaya, adat istiadat, kearifan lokal setempat, adanyan kendala dari pihak penyelenggara dalam memberikan sosialiasi kepada pemilih kelas XII yang telah berumur 17 tahun dengan adanyan pandemi Covid 19, pendidikan disekolah kurang maksimal juga dalam memberikan pendidikan politik karena siswa sekolah dari rumah.

\section{REFERENSI}

Aris Riswandi Sanusi, Cecep Dermawan, 2016. Implementasi Pendidikan Politik Dalam Membentuk Karakter Kepemimpinan Lintas Budaya Pada Generasi Muda Demi Mewujudkan Budaya Politik Pancasila (Studi Deskriptif Terhadap Organisasi Kepemudaan Gerakan Pemuda Ansor Jawa Barat. JPIS Jurnal Pendidikan Ilmu Sosial Vol. 25 No. I.

Asmika Rahman, Suharno, 2019. Pelaksanaan Pendidikan Politik Melalui Pembelajaran Pendidikan Pancasila Dan Kewarganegaraan Untuk Meningkatkan Kesadaran Politik Siswa. Jurnal Ilmiah Pendidikan Pancasila dan Kewarganegaraan Vol 4 No 2.

Chris Apandie', Endang Danial Ar², 2019. Huma Betang: Identitas Moral Kultural Suku Dayak Ngaju Kalimantan Tengah Jurnal Of Moral and Civic Education Vol 3 No. 2
Dwira Kharisma, 20I5. Peran Pendidikan Politik Terhadap Partisipasi Politik Pemilih Muda. Jurnal Politico Vol 4. No 2.

Husein Umar, 2013. Motode Penelitian Untuk Skripsi dan Tesis Bisnis. Jakarta: PT Raja Grafindo Persada

Muhibbin Syah. 2010. Psikologi Pendidikan dengan Pendekatan Baru. Bandung PT Remaja Rosdakarya.

Ndraha, Taliziduhu, 20 I I. Kybernologi: Ilmu Pemerintahan Baru. Rineka Cipta. Jakarta.

Payerli Pasaribu, 2017. Peranan Partai Politik Dalam Melaksanakan Pendidikan Politik. JPPUMA: Jurnal IImu Pemerintahan dan Sosial Politik UMA Vol 5 No $I$.

Rahmat, Amarru Mufftie H, lqbal S. 2018. Seminar Nasional Hukum Universitas Negeri Semarang Volume 4 (3)

Ririn Oktarina, Ribuwati, 2018. Penerapan Pendidikan Berbasis Kearifan Lokal Di SD Negeri 8 Rambutan Kabupaten Banyuasin Menuju Global Citizen. Prosiding Seminar Nasional 21 Universitas PGRI Palembang 05 Mei 2018.

Surabakti, Ramlan 1992. Memahami Ilmu Politik, Gramedia Widya Sarana Jakarta

Sunarso, 2007. Pendidikan Politik Dan Politik Pendidikan. Jurnal Civics vol 4 (2)

Sarwono, Jonathan, 2006. Metode Penelitian Kuantitatif dan Kulitatif. Graha IImu. Yogyakarta.

Sugiyono. 2015. Metode Penelitian Kuantitatif, Kualitatif, dan R\&D. Bandung: Alfabeta

Suwarno, 2017. Budaya Huma Betang Masyarakat Dayak Kalimantan Tengah Dalam Globalisasi: Telaah Konstruksi Sosial Lingua Vol I 4 No I.

Hasil Wanwancara Komisionr KPU, Anggota Partai Politik, Guru Kelas XII dan Siswa Kelas XII di Kecamatan Pahandut Kota Palangka Raya 